\title{
Samoan Pioneer Wives and 'Home': From the Experiences of Living in Japan more than 20 years
}

\section{KURAMITSU Minako}

Department of Geography and Environmental Studies, Ochanomizu University; 2-1-1 Otsuka, Bunkyo-ku, Tokyo, 112-0012, Japan. E-mail: kuramitsu.minako@ocha.ac.jp

Received October 15, 2015; Accepted November 14, 2016

\begin{abstract}
Place' is a core concept in human geography and scholars have focused on how globalization has affected 'place' since the 1990s. Despite findings that 'place' is socially re/constructed under globalization's fluidity, the relationship between 'place' and migration, which certainly shape and are shaped by globalization, has not been the subject of much academic attention from a perspective of migrants themselves. Within this context, this article aims to explore the relationship between 'place' and migration-particularly that between 'home' and marriage migrantsthrough life stories of three Samoan pioneer wives, who married Japanese men and have been living in Japan for over 20 years. As a result, the following three findings were identified. First, creating a 'home', in the sense of crafting a new life in Japan, has been a long and challenging process, and a good relationship with their husbands' families and acquisition of the Japanese language were necessary for Samoan wives to create a 'home' in Japan at an early stage. Second, the Samoan wives made a 'home' of their Samoan network, which enabled them to communicate with other Samoans and maintain connections to their home country. Last, creating or recreating a 'home' is a personal experience, influenced by how they grew up in Samoa and how they became accustomed to Japanese society.
\end{abstract}

Key words place, migration, home, marriage migrants, Samoan pioneer wives

\section{Introduction}

International marriage (kokusai kekkon in Japanese) $)^{1}$ is not a new phenomenon. Nevertheless, it remained relatively uncommon in Japan until after World War II. In 1965, when data collection began, the total number of international marriages was just over 4,000 (Figure 1). Such marriages grew rapidly, especially from the mid1980s, and were relatively common by the 1990s. After the number of international marriages peaked in 2005, they were down by half in under a decade, although the 2013 total remained five times higher than that of $1965 .{ }^{2}$ Whereas only one out of 250 marriages was international in 1965, international marriages comprised one out of 30 by $2013 .^{3}$

One factor underlying the rapid increase in international marriages from the mid-1980s was the surge in labor migration in conjunction with the number of migrant workers who lived in Japan for extended periods. At the same time, two new patterns in international marriages emerged. First, marriages between Japanese men and foreign women exceeded those of Japanese women and foreign men and, secondly, nationalities of foreign husbands substantially diversified (Kudo 2009b: 3 ). In line with these trends, a sociology of international marriages was established in the 2000s (Yagasaki 2010:
92), wherein roughly a dozen studies were undertakenespecially in relation to the theme of multiculturalism. ${ }^{4}$

Today, international marriages are becoming commonplace, yet the question remains: Is Japan a better place to live for foreigners? In this regard, Qu (2009: 273) writes that foreign wives generally face sizeable difficulties in Japan.

Foreign wives face extraordinary circumstances with regard to the Japanese social structure. There are various racisms and gender discrimination, and a continual demand to swiftly integrate into the patriarchallyorganized Japanese families, which can be culturally isolating. Many women marrying Japanese men face multiple cultural, social, and personal conflicts in the processes of adjusting to Japanese culture. Depending on their countries or regions of origin, the extent to which they experience sexual and racial discrimination might be enhanced. Young foreign wives are especially vulnerable because they are under pressure to adapt to long-term residency, loneliness, and Japanese customs, and they are compelled to quickly integrate into the Japanese way of life as a whole. Due to these circumstances, numerous patients manifest various psychosomatic symptoms, such as a sense of loneliness and a sense of inferiority deriving from personal denial of 


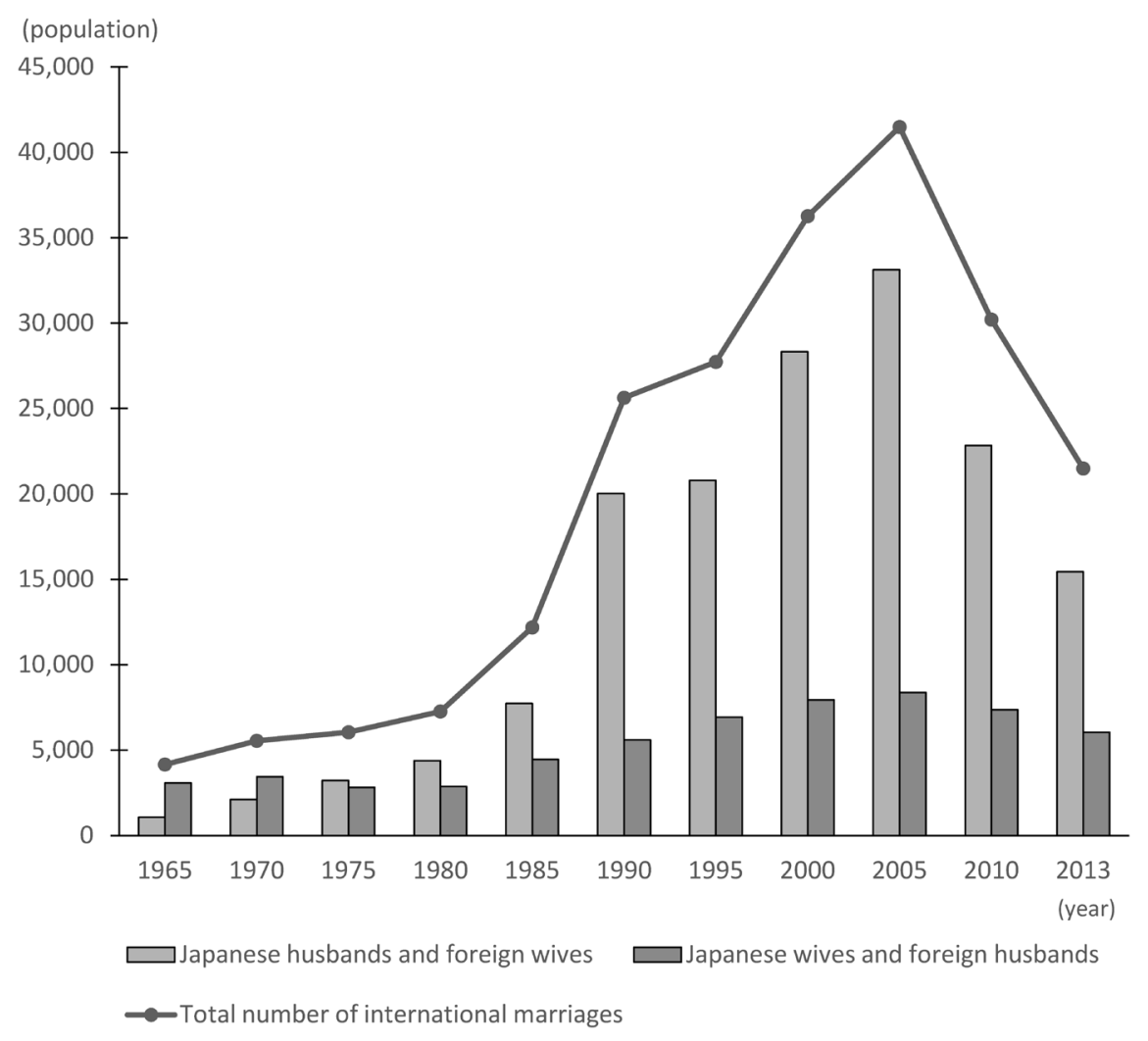

Figure 1. The number of international marriage in Japan (1965-2013).

Source: Ministry of Health, Labour, and Welfare of Japan. 2015.

http://www.mhlw.go.jp/toukei/saikin/hw/jinkou/suii10/ (last accessed 10 September 2015).

difference, and feelings of tremendous stress (translated by the author).

Despite the advance of globalization, Japan has not yet become more open in terms of immigration policy and acceptance of multiculturalism. As for policy, the Japanese government accepts only a minimal number of international migrants each year. Moreover, people in Japan tend to regard the country as ethnically and culturally homogeneous, ${ }^{5}$ even though the number of foreign nationals in Japan has been gradually increasing since 1965-with approximately 2,033,600 resident foreign nationals at the end of $2012 .^{6}$

Against this background, this article focuses on Samoan pioneer wives in Japan. The term "Samoan pioneer wives" refers to Samoan women who married Japanese men and have been living in Japan for over 20 years. While foreign nationals comprise a minority in Japanese society, Samoan women and men comprise a minority among foreign nationals in Japan. Official records show that two Samoans who entered Japan in 1963 were the first to do so following World War II. ${ }^{7}$ At the end of 2012, the Immigration Bureau of Japan officially recorded 57 Samoans in Japan: 24 men and 33 women. Out of all 57, eight had a spouse visa and 21 had permanent residency. ${ }^{8}$ While even the Samoan wives themselves are not sure of who among them arrived in Japan first, they did know that they arrived at a time when international marriage was not so prevalent. The interviewee of mine who arrived earliest stated that at least five Samoan wives had preceded her. In 2013, at least eight Samoan pioneer wives were staying in Japan.

Samoa is a small island nation in the South Pacific with a total population of 187,820 as of $2011 .{ }^{9}$ Generally speaking, two elements of Samoan society ought to be considered to effectively contextualize the lives of Samoan wives in Japan. The first one is the emphasis on fa'aSamoa, or Samoan customs and traditions, in every single aspect of daily life. The fa'aSamoa is based on a chiefly system that allows the chief to execute authority. The core unit of this system is the 'aiga, or kinship groups consisting of several extended families, located within the village. The chief is appointed by consensus of all 'aiga members, both male and female. According to fa'aSamoa norms, the prosperity of the 'aiga as a whole is paramount. This means that each member of the 'aiga is expected to behave not out of self-interest, but in the interest of the family in the stratified system. Thus, 
Samoans typically observe a principle of "family first" in their daily lives and view family matters as of utmost importance.

In such a situation, Samoan women normally inhabit two different statuses. On the one hand, they carry a higher rank than men within their own 'aiga based on the idea of sister-brother relationships (feagaiga), which is the primary foundation for gender relations in the Samoan society (Schoeffel 1978). Based on the feagaiga, brothers always respect sisters' opinions on family matters in the 'äiga. ${ }^{10}$ Even after marriage, woman keep their high status in their 'aiga whenever they return to the village. As a wife, on the other hand, women have no status in the husband's village. In particular, nofotane, or untitled men's wives, have to follow any instructions from not only the husband but also the husband's 'äiga. As a result, many young Samoan wives attempt either to reside with their own families or to inhabit homes separately from both families in contemporary Samoa. ${ }^{11}$

The second element is the marked mobility of contemporary Samoans beyond national borders. Many have taken up residence overseas, outside of Samoa. In particular, a considerable number have migrated to New Zealand, Australia, and the United States since the 1950s. The sum of all Samoans in these three countries is said to exceed the population in Samoa today. Hence, most Samoans have close relatives in these countries. Samoan migrants, and especially first generation migrants, send remittances and other items to their families in response to requests. The second and third generation of migrants visit their home country and actively maintain ties with their kinship networks.

This article aims to explore the creation of 'place' by Samoan pioneer wives based on their life stories. It is composed of the following three parts: first, in order to consider the creation of 'place, I will briefly review previous works on the relationship between 'place' and migration, especially those relating to the idea of 'home'; second, to show how they have lived for over 20 years in Japan, I will depict the life stories of three Samoan pioneer wives; and, last, I will attempt to consider how Samoan pioneer wives have created a 'home' to survive in Japan.

\section{'Place,' 'Home' and Migration}

'Place' is a core concept in geography, developed in the 1970s when humanistic geographers approached 'place' as a subjectively sensed and experienced phenomenon (Henderson 2009: 539). In the 1990s, scholars focused on how globalization has affected 'place' with many finding that 'place' is socially re/constructed under globalization's fluidity (e.g. Massey 1996; Harvey 1996). Migration or human mobility, especially when transnational, shape and are shaped by globalization; however, the relationship between 'place' and migration has not been the subject of much academic attention. ${ }^{12}$ While migrants are often indeed associated with the onset of change to a familiar setting, the role of 'place' in the lives of migrants themselves has not been greatly explored.

In this regard, the idea of 'home' might provide a clue for consideration of the relationship between 'place' and migration, and 'place' for migrants themselves. ${ }^{13}$ The idea of 'home' is defined by Cresswell (2004: 24) as, "the most familiar example of place and its significance to people," yet this simple word also contains multiple other meanings and connotations of humanity. In human geography, 'home' is defined as follows.

home An emotive place and spatial imaginary that encompasses lived experiences of everyday, domestic life alongside a wider sense of being and belonging in the world. As a space of belonging and ALIENATION, intimacy and VIOLENCE, desire and fear, the home is invested with emotions, experiences, practices and relationships that lie at the heart of human life (see EMOTIONAL GEOGRAPHIES). Geographies of home span MEMORY and nostalgia for the past, EVERYDAY LIFE in the present, and future dreams and fears, and are imagined and materialized on SCALES from the domestic to global (Blunt and Dowling, 2006). Through its internal intimacies and connections with the wider world, the home is 'perhaps the most emotive of geographical concepts, inextricable from that of self, family, nation, sense of place, and sense of responsibility toward those who share one's place in the world' (Duncan and Lambert, 2004, p. 395).

(Blunt 2009: 339-341, Emphasis in all caps from original)

For many migrants, 'home' means roots: where they come from and where they still experience a sense of belonging, even though they may be away. Representation of the Japanese diaspora in the United States and Brazil, as presented within Japanese television dramas, documentaries, and narratives present multifarious images of Japan as a home country. ${ }^{14}$ The first generation of migrants experience nostalgia for Japan, while later generations, who may not have visited Japan yet, might harbor adoration. 'Home' as the place of one's roots seems to remain important to many migrants over several generations. 
Even today, 'home' in this sense could be considered to loom large in migrants' lives. For example, Kudo in her research on Pakistani husbands and Japanese wives in Japan noted that many Pakistani husbands who had Pakistani family scattered across the world, regarded Pakistan as a place of keeping connections with family networks (Kudo 2009b: 7-8).

Creating and/or constructing a 'home' in the place of one's arrival is also significant in most migrants' lives. Since migrants often constitute a minority, thus making them relatively powerless within host societies, 'home' could provide them a sense of belonging, safety, resistance, and empowerment. ${ }^{15}$ Indeed, various patterns in creating 'home' have been reported. For instance, Pratt (1999, quoted in Cresswell 2004: 82-85) described how a Filipina domestic worker decorated a room in the house of her employer to make herself visible. This example showed how important it is for migrant laborers to create their own place to construct an identity. Kudo, referred to above, examined the meanings of a mosque newly constructed in the 1990s in a suburb of Tokyo as felt among Pakistani husbands and their Japanese wives. Pakistani husbands, most of whom were migrants and self-employed, regarded the mosque as not only as a functional place for religious practice but also as a place for forming networks for getting along in Japan. They also exchanged business information through mosque gatherings. Japanese wives, who converted to Islam to marry, were newly experiencing life as a minority in Japanese society and found that Japanese peers could not necessarily understand issues they faced in their married lives. Mosques provided a place for them to form new connections with others in similar circumstances, therefore enabling them to re/construct their identities as Islamic wives in Japan (Kudo 2009a: 120-123).

In this way, the creation and construction of a 'home' is indispensable to migrants seeking to survive in new settings. For marriage migrants, however, doing so may involve conflict, negotiation, and/or alienation, particularly owing to the different cultures and customs that each spouse brings into the marriage. According to Hamano in his research on Japanese female marriage migrants to Australia, 'home' as experienced in one's household is not only a space where wives may find psychological comfort with family; it is also a space where cultures clash, and where emergent cultural values and norms are negotiated and reconstituted (Hamano 2013: 55). Shirata explored the case of a Singaporean wife who could not create a 'home' within her household that made her feel as if she belonged or was accepted, thus motivating her to seek such a place in a work environment (Shirata 2009: 80).

\section{Samoan Pioneer Wives and Their Life Stories}

Previous works indicate that the creation and re/construction of 'home' is significant to migrants in their efforts to survive in new settings. Does this also apply to Samoan pioneer wives, a true minority in Japanese society? This section will illustrate their life stories to investigate how the wives have created a 'home' to survive in Japan. Data on the life stories of three Samoan pioneer wives, Peta, Sina and Emi (all anonymized), was collected through semi-structured interviews conducted in February and July of 2013. Interviews with Peta and Sina were conducted in English, while Emi chose Japanese for her interview. Peta's husband joined for her interview and contribute to recollections of the past. ${ }^{16}$

Table 1 provides brief background information relating to the three Samoan pioneer wives. They were all in their 50s at the time of the interviews and had come to Japan in the early or mid-1980s, just before the number of international marriages increased. Peta and Sina had acquired permanent residency and Emi was a naturalized citizen. At the time of the interview, Sina and Emi were living in the Tokyo metropolitan area, while Peta was residing in a small town near Aichi prefecture. All three women met their Japanese husbands in Samoa while the men were working as international volunteers. The husbands were salaried employees in Japan: Peta's husband was working as an architect, Sina’s husband was working

Table 1. Three pioneer wives' backgrounds

\begin{tabular}{|c|c|c|c|}
\hline & Peta & Sina & Emi \\
\hline Birth year (age at interview time) & $1961(52)$ & $1959(54)$ & $1960(52)$ \\
\hline Arrival in Japan (age) & January 1985 (24) & May $1982(23)$ & November 1984 (24) \\
\hline Children (birth year) & Son (1983), Daughter (1989) & 2 daughters $(1990,1994)$ & Son (1986), Daughter (1989) \\
\hline Current place of residence & Small town near Aichi prefecture & One of the 23 wards in Tokyo prefecture & Surburb city in Kanagawa prefecture \\
\hline Current visa status in Japan & Permanent resident & Permanent resident & Naturalized citizen \\
\hline
\end{tabular}

Source: Author's interviews in 2013. 
for a well-known security company, and Emi's husband was working at a European car company. Each of the couples has two children. As of 2015, Peta's two children have already married Japanese spouses, while Sina's two daughters are single and staying in Japan. Emi's son has married a Japanese woman and her daughter is single and staying in Japan.

\section{Peta's life story}

Peta grew up in a village about 10 kilometers away from Apia, Samoa's capital city located in the central northern part of Upolu Island. Her father was a high chief in the village and has 21 children including Peta and adopted siblings. Peta's husband was a close friend of one of her relatives and they met when he came to her village to play table tennis. After he returned to Japan, she found out that she was pregnant. Her mother was very upset and sent her away from the house. She stayed with both Japanese and Samoan friends until she one day received a call from a relative explaining that her mother was always crying to see her, prompting her to return home. From Japan, her husband wrote a letter each week and sent her money for medical check-ups. Six months later when he came back to Samoa, her mother had still not forgiven them.

Mom said that even if he (her husband) came, she did not want to see him. Then, I ringed my brother-in-law in Hawaii, and asked him to persuade her. My brotherin-law came over from Hawaii and said to my mom, "better to forgive him, because it is not only him [to make a girl pregnant]. You have to be happy. If it were other man, maybe he won't be coming any more. But he still come back to see her (Peta) and baby." Mom told him, "it's up to you, but I'm still not [happy]." My mom had a pride. You know, "baby first before marriage" is something like not really good in our custom. My father was a high chief. You should never get pregnant (she laughed). "First marriage and then baby."

According to her husband, Peta was very well-off girl. At home she had never cooked or ironed clothing like other Samoan girls did. Peta did not know anything about Japan but its name. She thought Japan was a part of China.

In January 1985, her husband came to Samoa for her and their first child, and the three returned to Japan together. Because it was winter her first impression of Japan was "snowy and cold." They initially spent two weeks at his brother's place in Tokyo, where her husband was trying to find a job. He thought it would be easier for Peta to stay in Tokyo, since the capital city is international. However, they ultimately moved to his hometown, a small town located near Aichi prefecture in Central Japan. There they rented an apartment near his elder sister's home. Seven years later, they moved to a house where they have continued to live until today.

Peta said that the harder things to get used to in Japan were food and language. At first, she could not eat any Japanese food and also could not cook. Her brother-inlaw and sister-in-law nearby often visited and helped her out a lot. Peta's husband said:

Peta did not go to any language school. She mostly learned Japanese by watching TV. She also joined a Japanese language class held by our town just before our children went to nursery school. She learned Japanese with the children too. She wrote Kanji down on a piece of paper and tacked these to the wall for 5 or 6 years. It took 13 years for her to pass the driver's license exam in Japan, even though she could drive a car.

Although Peta's husband recalled that she felt difficulties in "getting along with" relatives and neighbors, Peta herself did not feel any difficulties in getting along with her family-in-law.

-Can you tell me about your relationship with your husband's family?

Peta: I had no parents close to me. So I thought his parents were my parents. We were very close and they always cared for me and kids. Even my sister-in-law was very nice to us. She came and took me and my son to shopping. They taught me how I could do shopping and how I could use Japanese money.

Peta's husband: My sister is 13 years older than I. So she thought of Peta as her baby brother's cute little wife. She always took her around with saying "my little brother's wife"... The neighbors' association also helped her. Our neighbors were very nice and kind to her. They are ojiichan and obachan (old men and women) and often praised her by saying, "You're remarkable (erai)!" and, "you're doing well in Japan." One day, one elderly male neighbor chased away a salesman for her.

Peta did not feel that there was a great difference between Japan and Samoa in terms of taking care of children. Her husband was working in Nagoya and did not have enough time to look after the children. Yet, her 
sister-in-law and her mother-in-law came to help her. When she had to go to meet teachers at her children's school, her husband always took a day off and went to the school with her.

Peta did not have any information on Samoans staying in Japan before she came. She also never thought of contacting other Samoans. However, whenever she or her husband received information that there might be a Samoan nearby, they always visited. They once drove to a resort hotel in Aichi prefecture when they heard that a performer there might be Samoan. The performer was Hawaiian, but they coincidentally ran into a Samoan man married to a Japanese woman employed at the hotel. Early on, Emi, one of three interviewees, came to visit them at times. Peta had a chance to get together with other three Samoan wives in Tokyo when the Samoan rugby national team came to Japan. She also remembered encountering in Japan two Samoan girls married to Japanese men, and one lived near her place.

In the beginning, Peta wrote back often to her family in Samoa. Peta and her husband easily recalled how expensive international calling was. She also went back to Samoa with her husband and her two children every three years, because her mother made her husband promise to do so when they married. They also invited Peta's mother to Japan twice, with one visit for cataract surgery. Although her mother passed away in 2008, she visits her elder brother and her family in Samoa annually. Peta also sent money to her family in Samoa, based on her mother's requests. Peta's husband said that he agreed to send money because it was common for Japanese people in Kyushu and Okinawa to send money to their parents too. Their son loved Samoa and sent clothing that he collected himself when Samoa underwent a grave tsunami disaster in 2009. He also tried to sell handicrafts from Samoa through the internet. One wall in their house was decorated with family photos, ula, or Samoan necklaces, a "21st birthday key" sent from Samoa, and a small altar with the Virgin Mary: all items commonly found in Samoan homes.

\section{Sina's life story}

Sina's hometown was a village located in central Apia. She was the second of 10 children between her parents. Sina met her husband when she went to play tennis with a friend, and he asked her to go out. She recalled that her life was up and down at that age, and she was not ready to start such a relationship. She was working part-time at a private primary school and was also planning to go to New Zealand. She, however, changed her mind after she found out that he was the kindest man she had ever met. She also did not like Samoan boys so much; she was interested in marrying a white man, just like her aunties married to New Zealanders.

I believed marrying him is the God plan for my life. It really took me to decide, because of my parents. I am the second of 10 children, and my brother has already left for America to work. My concern was about my parents. You know very much about Samoan [custom]. Our parents are most important.

- So was it easy for your family to accept your decision when you decided to marry?

No. Especially my mother. She did not like it...I think the reason was because I was the second and I had a responsibility for the family, especially two of them. Plus, I was the one who was taking care of everything of the family. I was working a part-time job and all sisters were still young. My father was the only one working in the family.

- How did you get permission to marry from your parents?

I think I did broke my mother's heart. It's nothing to do when you love somebody. I loved my parents so much, but I could not let it go, because both of us loved each other. Anyways, we got married and we came home to see my parents. And my mother was very shocked.

Sina and her husband had a civic marriage in front of friends, ${ }^{17}$ just before he left for Japan. Her parents were worried about her going alone to a place that they did not know well. Her mother asked her to stay in Samoa for a while to see how it went. Six months later, her parents finally gave her their permission to go to Japan.

In May 1982, when Sina turned 23 years old, she arrived in Japan on her own. She was excited to be in a new country and she thought she was ready for Japan. Although she did not know anything about Japan, she thought that all Japanese people were kind and friendly based on three years of friendships with Japanese people working in Samoa. Her first impression of Japan was that it was "huge of people," compared to Pagopago, the port town in American Samoa where she had travelled before. She started her life with her husband in a small housing complex in a Tokyo suburb, where her parents-inlaw were too. Sina and her husband moved twice within Tokyo prefecture and now reside in a house in one of Tokyo's 23 wards.

Sina found out that everything was difficult in Japan. Although she had thought Japanese people were kind 
based on her experiences in Samoa, her encounters in Japan were different. She also made a tremendous effort to learn the Japanese language.

I thought Japanese were cold-hearted people, but it was my misunderstanding because I hadn't known them. My family-in-law owned a small shop selling breads, so I went to help my mother-in-law every day. Speaking with customers was very helpful to learn more about the people and speaking with my mother-in-law was helpful to learn the language. My mother-in-law wanted me to improve my Japanese language, so that she put me into the Japanese language school in a city near our place. I went there once a week to improve my Japanese conversation. There I also met my boss, the principle of the kindergarten, where I am still teaching English.

Until she had her first child, Sina was teaching six classes every Friday and a special class for graduates of her Friday class on Wednesdays in the kindergarten. Her mother-in-law was a protestant and took Sina with her to church. When they moved to one of 23 wards in Tokyo around 1990, she found a Catholic church for Sina to attend. Currently, Sina's husband converted to Christianity and they all attend church together. Since she recalls her mother teaching her that "everything goes the god first," Sina has actively participated in church activities.

Regarding childrearing, Sina found out that her husband tended to spoil their daughters, while she was very strict. She also noticed that women have more responsibilities pertaining to the children at home, while working is more important than being with family for Japanese men.

- How about matters relating to your children's school? Yes, that was another hard case. For the sake of my children, I never miss anything from the kindergarten up to the university. I was also involved with the PTA. I just go, even though I did not understand and they (Japanese mothers) did not want to be my friends. I learnt something: I would understand who they were, what they wanted, and [their image of a] foreigner.

Before she left Samoa, Sina knew that a dancing group from Samoa was performing on a six month contract in a resort hotel in Aichi prefecture, because a girl from her village was a member. She asked her husband to take her to meet her friend there once she arrived in Japan. She always tried to establish contact with other Samoans, either those staying in Japan or those entering as trainees or students from Samoa. She longed to meet trainees from Samoa, because she could ask them to carry gifts to her family.

-When somebody came from Samoa, what kinds of things did you give them to bring back home?

Oh...most mealofa (gifts), you know, were money. At that time, they were US dollars.

-From your salary?

Yes. And my husband's salary as well. Of course, he is my husband.

-Anything else except for dollars?

Everything. You know, sometimes, you want to take the whole Japan to home, right? Because here, in Japan, what was amazing was that you have everything, compared to where we come from. So when you look at the shops the only thinking you remember is your family. Anyone you gifted, you know. That's the happiness for Samoan. I believe that comes from Samoan heart and culture, you know, "Family first!"

Today she continues to send money to Samoa depending on the situation, since her mother passed away. During her first year in Japan, she filled boxes with gifts and sent them often to Samoa. However, she now only sends small packages on special occasions such as Holy Communion and her sisters' graduations. Sina mostly wrote to her parents, because the more she called, the more she felt homesick. Until she had children, Sina went back to Samoa every two years to maintain family ties at times like funerals, weddings and birthdays. For her, however, the most important thing in returning to Samoa was to teach her daughters the other half of their roots. Currently she goes to Samoa either every year or twice a year.

\section{Emi's life story}

Emi was born in a village in the southeastern part of Upolu Island. When she met her husband for the first time, she was studying commerce and engineering at a Technical Institute in Apia where her husband taught as a volunteer. According to Emi, her husband brought her drinks and snacks when she would take breaks with friends under the trees. She could not see whether he was approaching her or not. Six months later, he waited for her at the school gates and they began walking together to his house near the school. She still wondered whether he just wanted to practice his English with her. Then he started giving her rides home and spent time teaching her 
mathematics. Two years passed in this way, as they spent time together, before his term expired. He insisted that he would not go back to Japan without her. Emi could not decide whether to go with him or not, because she still had one more year until graduation. Since he also wanted to see her parents, Emi took him to her village. Her parents did not know anything about them, and were very surprised. Her father refused to give them any permission to marry, while her mother disagreed because Japan was far relative to New Zealand, Australia, and the United States. She asked Emi what they could do if something happened to Emi in Japan. However, Emi's sisters made an effort to persuade their parents to support her decision.

Although Emi did not feel fear, she was worried about her husband's family, and especially her parents-in-law.

I felt very relieved when I knew his parents were teachers. I told him that I would definitely like to live with his parents. I really wanted to live with them.

-Wow! I don't think many Japanese women want to live with their parents-in-law.

That was not the case for me...because I wanted to live in Japan indefinitely so that I needed to learn the language as soon as possible. I was resolute that I would live in Japan for good. Then my decision was right. His parents were really... (she tries to express gratitude, but is stopped by tears).

In November 1984, Emi traveled to Japan with her husband, where they married. Emi's husband found a job before he returned to Japan and had to travel overseas soon after they started their new life in a suburb in Fukuoka prefecture. Although he wanted her to join him, Emi refused. She told him to go by himself for the six month project, because she had to stay in Japan to study. Emi's parents-in-law were retired, but ran a cram school in their house with another English teacher. She was heartened to see children studying at the school. She also learnt Japanese tea ceremony and flower arrangement from her mother-in-law. She felt so lucky that she hardly wished to return to Samoa.

However, in town...people initially looked at me like, "Oh, she is a foreigner, isn't she?" When I went shopping in the morning, for example, they were watching me somehow. Then I said to myself, "Fine! If you want to watch me, I will greet you," and I always greeted them. When I went shopping at the supermarket, I always had a pen and a piece of paper. While shop- ping, I just wrote the names of things down. That became very well-known among neighbors. They gradually remembered my name and called me by my name, which really made me happy. I also loved to get involved in children stuffs. When there were any events on children's stuff at the town hall, I always participated. I thought that since I was living in Japan, I had no choice but to do it. I thought it was better for me. Then I gradually learned the language, and I also started challenging myself by saying, "I'll get on a bus. I'll take a train." I also started to learn cooking and went to the class by train. My mother-in-law could not cook so well, because she had a house keeper at home while she was working. Then my cooking became better. I cooked special dishes for the New Year. My father-in-law told me "delicious" and I replied "thank you very much." Such moments were so enjoyable.

Emi also taught English at a kindergarten that her mother-in-law introduced her to. She stayed with her parents-in-law for about two years. After she gave birth to her first child, Emi moved to Dubai because of her husband's work. Her mother-in-law came to Dubai to help out when she had a second child there. Until she moved to Dubai, she was not sure about her Japanese ability. In Dubai's Japanese community, Japanese wives of Japanese businessmen were surprised that she could speak Japanese at all, so she felt fortunate. After their stay in Dubai, they also moved to Cyprus, and then came back to Yokohama. They settled down in a city by Yokohama, where they have stayed until today.

It was very difficult for Emi to "get along with people," especially other mothers. For instance, she recalled how surprised she was that every mother wore a suit at PTA meetings in Yokohama, while she wore T-shirt and jeans. She also felt shocked when she knew a child committed suicide because of bullying. She was worried that her children might get bullied because her children were physically big. Fortunately, such things never happened, because Emi and her children all made numerous Japanese friends.

Emi had no time to develop a network with other Samoans in Japan, because she moved overseas soon after arriving in Japan. She knew Peta because she met her at Peta's husband's farewell party in Samoa. After she came back to Japan with her family, she contacted one Samoan pioneer wife near her home. That wife introduced her to Sina and two other Samoan wives with whom she sometimes had meals. She also joined events held by members of the Samoan community in Japan with her husband and 
children.

Emi did not call her own family. She only sent postcards just 4 times a year. Today, she often calls to her sisters in Samoa using Skype. She sent shoes, sweets, and stationery for children in her family, but she never sent money unless her family asked.

If they asked me, I would surely send money. Even if I thought the reason they needed money sounded like a lie, I sent money. I just made my sisters promise to use the money only for their children's education.

Emi did not go back to Samoa for the first 18 years after she left, while her husband (at the time of the interview) had not gone back to Samoa since completing his volunteer work. Now she normally visits every year, often by herself.

\section{Discussion}

The life stories of the three Samoan pioneer wives illustrate how they have each created a 'home' to survive in Japan. In this regard, the following three findings were identified. First, creating a 'home' in the sense of crafting a life in Japan, has been a long and challenging process. It was not easy, and involved alienation from and negotiation with Japanese society. These tensions emerge in stories of learning the Japanese language and how to manage "getting along with people." Regarding the early stages of their lives in Japan, two things were indispensable for Samoan wives to create a place for themselves in Japanese society. One was acquisition of the Japanese language. All three life stories indicated that the wives gradually gained access to local communities and felt like they were accepted by Japanese society as they improved their Japanese ability. The other was various supports provided by their husband's families. In the beginning, each of them lived near or with families-in-law who helped teach them how to live in Japan. Moreover, their in-laws also provided them with opportunities, such as introducing them to friends or teaching jobs, thereby expanding the wives' scope of daily activities. In this way, a good relationship with their husbands' families was crucial to creating a 'home' in new settings for marriage migrants.

Second, connecting to 'Samoa' was a part of creating a 'home' to survive in Japan. Samoan wives kept their connections to Samoa in two different ways: associating with other Samoans in Japan and maintaining ties to their own family. Regarding the former, once Samoan wives had chances to meet other Samoans, including other wives, they consistently did so and continue to do so now. However, the extent to which they could do so depended on location and time. ${ }^{18}$ These life stories and observations ${ }^{19}$ reveal that the Samoan community in Japan could be identified as a loose and flexible network. Although they did not have a physical space to get together for regular meetings with regular members, they each built a provisional 'home' as needed to welcome any Samoans coming to Japan. ${ }^{20}$ As for the latter, all Samoan wives actively maintained ties with their own families in Samoa. Their recollections regarding expensive international calls, inviting their mothers to Japan and delivering remittances through multiple means underscore the importance of family despite distance. For instance, Sina's case shows that associating with Samoans in Japan also served to connect her to her own family. Moreover, the decorations in Peta's house give evidence that Samoan material culture was an important component of her Japanese home.

Last, creating or recreating a 'home' is a personal experience, influenced by how the wives grew up in Samoa and how they spent time in Japanese society. Comparing Emi and other two wives, for instance, a sense of belonging, which is the key element of 'home', differed starkly. Especially, Sina emphasized the importance of Samoa as follows.

Nowadays, it is very common for people to marry a foreigner. But when I first came to Japan, foreigners were not so common. Foreign (International) marriages were not so common. I was the second foreigner to live in the small housing complex in my suburb of Tokyo. [Japanese] people thought we (foreigners) were from another planet. At that time, I had African, American, Korean, and Brazilian friends whose husbands were Japanese. Many of them found it very difficult and had a hard life. So many of my friends, they [divorced and] left. They could not carry on, you know. Even me, I went through a very difficult life. [What made me carry on were] my faith, peace, prayer, and hope. That's why I never forget the place where I came from, the family I was raised in, and the parents who gave me life.

For Sina, Samoa was still 'home,' a place that she strongly identified with. She explained that she brought her daughters to Samoa because she wanted them to understand their roots. Emi, on the contrary, was determined to live in Japan for good and actively made Japan her 'home.' Such an attitude could be seen in how she chose Japanese 
for her interview and that she was a naturalized citizen. Moreover, she mentioned her ideal future as follows.

-Which is easier, to stay in Japan or in Samoa? Surely in Japan. I wish I could have grandchildren here (Japan). If I go back to Samoa, what shall I do? I have nothing to do in Samoa. But here, I have many things. I have to study more. I will continue to study as I get older.

After she spent for more than 20 years in Japan, Samoa was not a 'home' in a sense, where Emi could feel belongingness. In this way, the life stories of the three Samoan pioneer wives, all of whom came from Samoa at around the same age and the same time, indicate that they have not created or recreated the same 'home' to survive in Japan.

\section{Concluding Remarks}

This article explored the relationship between migration and 'place'-particularly that between marriage migrants and 'home'-through the experiences of Samoan pioneer wives. The research on the life stories of Samoan wives is still incomplete, and further study of the following three points is required. First, there should be investigation of how Samoan wives envision 'home' as encapsulating their roots. As mentioned in the introduction, family, or 'āiga, is of utmost importance for most Samoans. However, this article focuses only on the creation of a 'home' in Japan and, thus, does not explore feelings as directed towards the home country, Samoa, and the natal family, 'aiga. Generally speaking, Samoan migrants take pride in Samoa and maintain ties through their own kinship network. As shown in the life stories, however, the extent to which Samoan wives kept contact with their family, how often they returned home, and how they spoke about Samoa varied. Moreover, Sina sometimes implied that "where I was coming from" was very important for her life in Japan. It is necessary to examine how their roots in Samoa have influenced the creation of a 'home' in Japan and how they have recreated 'home' as a place for holding roots.

Second, 'home' as a household, which Hamano recognized as a space where cultures could clash, and where cultural values and norms are negotiated and reconstituted, should be explored in greater depth. In their life stories, the Samoan pioneer wives hardly had serious negotiations or clashes with their family-in-laws. One reason was because they were wives who were expected to follow their in-laws' instruction according to Samoan norms, while the other was because they had not always been living together with their husbands' families. Moreover, Peta and Emi stated that they each regarded their parents-in-law as their own parents, because their parents were so far away. However, Sina and Emi implied that their experiences of raising children in Japan were challenging. How foreign wives negotiate with their Japanese husbands and Japanese society is a crucial point for understanding how foreign wives make their households into 'homes' where they keep their own cultural values and beliefs in new settings.

In relation to the above, lastly, there also should be further exploration into how gender norms in the fa'aSamoa, such as long-held and culturally ingrained Samoan views of mothering, families, and acting as wives, influence women's approaches to creating a 'place' or 'home.' In interviews, Samoan pioneer wives refrained from presenting their experiences in a negative light. Rather, they seemed to assist their husbands as wives and raise children as Japanese mothers would. It ought to be fascinating and fruitful to investigate normative views held by Samoan wives regarding what "women should be" in the fa'aSamoa and to consider how those perceptions influence the creation of a new 'place' or 'home' in another world.

\section{Acknowledgements}

This work was supported by JSPS KAKENHI Grant Number 23242053. The article was substantially revised based on "Living in Japan for more than 20 years: The experiences of Samoan pioneer wives. In Building Global Networks through Local Sensitivities: Japanese Researchers' Contribution to Gender and Geography, eds. K. Kumagai, and Y. Yoshida, 35-41. Tokyo: Ochanomizu University." I would like to express my appreciation for the three Samoan women who so kindly granted me interviews and shared their precious life stories, and my Samoan partner who provided such valuable opportunities. Fa'afetai tele lava.

\section{Notes}

1. International marriage (kokusai kekkon in Japanese) has been increasingly utilized as an academic term since the 2000s. Marriages between individuals who are of different racial and/or cultural backgrounds may also be called "interracial marriages," "intercultural marriages," or "mixed-cultural marriages" (Kamoto 2008: 1-8). 
2. The number of international marriages has gone into decline because of a decrease in marriages between Japanese men and Filipinas due to the tightening of control over entertainer visas for Filipinas in 2005 (Kamoto 2014: 6).

3. Ministry of Health, Labour and Welfare of Japan. http://www. mhlw.go.jp/toukei/saikin/hw/jinkou/suii10/ (last accessed 10 September 2015).

4. On CiNii (Scholarly and Academic Information Navigator), a database of popular magazine and journal articles, books, and dissertations in Japan, there were 496 articles on "international marriage (kokusai kekkon in Japanese)." Out of those, 387 were published after 2000 (last accessed on 18 September 2015) with markedly diversifying themes. There were also 28 articles on "female marriage migrants (kekkon ijyu jyosei in Japanese)" published since 2008 (last accessed 20 September 2015).

5. To give one example, the 2015 Miss Universe Japan was the first woman of mixed descent to win the beauty pageant. She was born and raised in Nagasaki and Japanese is her first language. Her father is African-American and her mother Japanese. After awarding her the title, the pageant has been subject to criticism because, according to detractors, she was not a "full-Japanese" and did not look Japanese (Hosokawa 2015; Withnall 2015).

6. The number of foreign nationals staying in Japan in the mediumand the long-term was the lowest in 2012, but the most recent number is 2,121,831 in the end of 2014 (Ministry of Justice of Japan. Zairyu Gaikokujin Toukei. http://www.moj.go.jp/housei/ toukei/toukei_ichiran_touroku.html (last accessed 18 September 2015)).

7. Samoa achieved its independence in 1962.

8. The latest statistics show that 65 Samoans ( 30 men and 35 women) have maintained medium- and long-term stays in Japan as of the end of 2014. Out of all 65, ten had a spouse visa and 24 had permanent residency (Ministry of Justice of Japan. Zairyu Gaikokujin Toukei. http://www.moj.go.jp/housei/toukei/toukei_ichiran_ touroku.html (last accessed 18 September 2015)). However, the number of Samoan wives in Japan is unclear because some Samoan pioneer wives have become naturalized citizens and no statistical data of Samoans by both visa status and gender exists.

9. Samoan Bureau of Statistics. Population \& Demography Indicator Summary. http://www.sbs.gov.ws/index.php?option=com_content \&view $=$ article\&id $=53 \&$ Itemid $=36$ (last accessed 30 July 2014).

10. Even though Samoan women have the right to be appointed as chief, few Samoan women hold titles relative to men. In this regard, Schoeffel explained, "every Samoan women has by right a strong and respected voice in the affairs of her own 'aiga [sic.] particularly in the bestowal of titles. This affords women opportunity to wield direct political influence over male kin" (Schoeffel 1979: 18).

11. Untitled men living with wives' family are called as faiava. Nofotane and faiava are usually young and have to serve their family-in-laws, such as doing all chores and giving what salary they earn. For instance, a Samoan woman, who migrated to New Zealand in 1966, stated that she could not do anything for her own children with her family-in-laws, so she decided to move to New Zealand (Author's interview in 2009). According to Schoeffel, however, most Samoan women of mature years have considerable influence within the 'aiga of their husbands, even though they formally have no such right (Schoeffel 1979: 18).

12. In this regard, Mendoza and Morén-Alegret (2013: 763-764) point out that, "[t]he discussion of 'place' and 'sense of place' has undoubtedly been very widespread in geography since the mid1970 s, but with few exceptions the analytical potential of these concepts has yet to be fully achieved as far as the study of migratory movements is concerned. Certainly, there is a shortage of broad reflection in the academic literature regarding methods for studying the relationship between 'place' and 'migration.'

13. Fukuda (2008) provides an excellent review of growing interest in 'home' and how migrants create 'home' as discussed in cultural geography within English-speaking countries.

14. For example, the Japanese television drama "The man of the Tokyo Olympics" (Fuji Television 2014) presents the story of a second generation Japanese-American dedicated to seeing Tokyo host the 1964 Olympics games and actively supporting the bid made by his 'home' country. The documentary "104 year old poster girl: The daily lives of Hawaiians of Japanese descent" (BS Japan 2012) introduced nostalgia that Hawaiians of Japanese descent had for Japan.

15. bell hooks (1990) points out that a black child experiences home as "a place of care and relative freedom" in an oppressive white world (Cresswell 2004: 25-26). This work is often used as an example of "challeng[ing] a white, liberal feminism that has understood the home primarily as a site of oppression for women," as posed by black feminists (Blunt 2009: 341).

16. All interviews were recorded by IC recorder after getting interviewees' permission. Quotes from the interviews are based on the author's transcription from recorded data. Neither the author nor the interviewees were native English speakers. However, the specific wording of interviewee responses is very important for contextual understanding of their situations. Therefore, quotes from interview remain in their original conversational form with minimal correction. Transcriptions in Japanese are translated into English by the author.

17. Sina invited her mother to Japan for their official wedding at a Catholic church in 1997.

18. For instance, neither Peta nor Emi had many chances to meet Samoans, as Peta lived in a small town near Aichi prefecture, and Emi lived outside of Japan due to her husband's job. As time passed, Emi also found that Samoan wives did not see each other often owing to their busy schedules.

19. Since around 2002, the author has joined several meetings of Samoans in Tokyo through Samoan friends.

20. Following the establishment of the Samoan embassy of Japan in 2009, there have been regular embassy gatherings, especially on Samoa's Independence Day, Christmas, and New Year. The Samoan community is gradually developing an association. For instance, when Samoa faced a tsunami disaster in 2009, the Samoan community in Tokyo held a charity event to raise donations. They also made a charity visit to evacuation centers after the Great East Japan Earthquake in 2011.

\section{References}

Blunt, A. 2009. Home. In The dictionary of human geography, 5th edition, ed. D. Gregory, R. Johnston, G. Pratt, M. J. Watts and S. Whatmore, 339-342. Chichester: Wiley-Blackwell.

Blunt, A. and Dowling, R. 2006. Home. London: Routledge.

Cresswell, T. 2004. Place: A short introduction. Oxford: Blackwell Publishing.

Duncan, J. S. and Lambert, D. 2004. Landscapes of home. In A companion to cultural geography, ed. J. S. Duncan, N. C. Johnston and R. H. Schein, 382-403, Oxford: Blackwell.

Fukuda, T. 2008. Putting 'home' in geographical contexts: A review of cultural geography studies. Japanese Journal of Human Geography 60: 403-422. (JE)

Hamano, T. 2013. Making a 'home' in Australian suburbia: Case studies of Japanese female marriage migrants living in Western Sydney. Journal of Australian Studies 26: 49-67. (JE) 
Harvey, D. 1996. Justice, nature \& the geography of difference. Massachusetts: Blackwell.

Henderson, G. 2009. Place. In The dictionary of human geography, 5th edition, ed. D. Gregory, R. Johnston, G. Pratt, M. J. Watts and S. Whatmore, 539-541. Chichester: Wiley-Blackwell.

hooks, b. 1990. Yearning: Race, gender, and cultural politics. Boston: South End Press.

Hosokawa, N. 2015. Hafu wo meguru sabetsu to gensho (1) (Fantasy and discrimination on mixed race in Japan). In Asahi Shimbun 4 September 2015, http://digital.asahi.com/ special/kotoba/jinken/SDI201508059633.html (last accessed 18 September 2015) (J)

Kamoto, I. 2008. Kokusai kekkon ron!? Kyoto: Houritsubunkasha. (J)

Kamoto, I. 2014. Marriage migrants and "multicultural coexistence" from the perspective of extraordinary events: Great earthquakes and divorce. Contemporary society bulletin (Kyoto Women's University) 8: 1-33. (JE)

Kudo, M. 2009a. Creating Muslim space in the suburbs of Tokyo and beyond: Case studies of Pakistani men and their Japanese wives. Japanese Journal of Cultural Anthropology 74(1): 116135. (JE)

Kudo, M. 2009b. (Re)Creating "Relatedness" through a transnational family: Case studies of Pakistani migrants and their Japanese wives. Kyoto Working Papers on Area Studies: G-COE Series 75: 1-10. (JE)

Massey, D. 1996. A global sense of place. In Exploring human geography: A reader, ed. S. Daniels and R. Lee, 237-245, New York: Halsted Press.

Mendoza, C. and Morén-Alegret, R. 2013. Exploring methods and techniques for the analysis of senses of place and migration. Progress in Human Geography 37: 762-785.

Pratt, G. 1999. Geographies of identity and difference: Making boundaries. In Human geography today, ed. D. Massey, J. Allen and P. Sarre, 151-168, Cambridge: Polity.

$\mathrm{Qu}, \mathrm{X}$. 2009. The research movement and perspective of international marriages in Japan. Bulletin of the Graduate School of Education, the University of Tokyo 49: 265-275. (J)

Schoeffel, P. 1978. Gender, status and power in Samoa. Canberra Anthropology 1(2): 69-81.

Schoeffel, P. 1979. The origin and development of women's associations in Western Samoa, 1830-1977. Journal of Pacific Studies III: $1-21$.

Shirata, C. 2009. Kokusai kekkon ni yotte rainichi shita gengo shosuha no hahaoya wa dainigengokankyou de donoyouna sekai wo tsukuri ageteiruka. Japanese language education 38 : 78-80. (J)

Withnall, A. 2015. Miss universe Japan Ariana Miyamoto faces criticism for being 'not Japanese enough'. In the Independent, 25 March 2015. http://www.independent.co.uk/news/people/ miss-universe-japan-ariana-miyamoto-faces-criticism-forbeing-not-japanese-enough-10132732.html (last accessed 18 September 2015)

Yagasaki, N. 2010. Publication trend of the books on intercultural marriages in contemporary Japan. Bulletin of Tokyo Gakugei University. Hummanities and social sciences, II 61: 79-101. (JE)

(J) written in Japanese

(JE) written in Japanese with English abstract 